\title{
Dietary glycaemic index, glycaemic load and breast cancer risk: a systematic review and meta-analysis
}

\author{
HG Mulholland*,', LJ Murray', CR Cardwell' and MM Cantwell' \\ 'Cancer Epidemiology and Prevention Research Group, Centre for Clinical and Population Sciences, Queens University Belfast, Mulhouse Building, \\ Royal Victoria Hospital Site, Grosvenor Road, Belfast, BTI 2 6BJ, UK
}

\begin{abstract}
This systematic review aimed to examine if an association exists between dietary glycaemic index (Gl) and glycaemic load (GL) intake and breast cancer risk. A systematic search was conducted in Medline and Embase and identified I 4 relevant studies up to May 2008. Adjusted relative risk estimates comparing breast cancer risk for the highest versus the lowest category of Gl/GL intake were extracted from relevant studies and combined in meta-analyses using a random-effects model. Combined estimates from six cohort studies show non-significant increased breast cancer risks for premenopausal women (relative risk (RR) I. I4, 95\% Cl 0.95- I.38) and postmenopausal women (RR I.II,95\% Cl 0.99-1.25) consuming the highest versus the lowest category of Gl intake. Evidence of heterogeneity hindered analyses of $\mathrm{GL}$ and premenopausal risk, although most studies did not observe any significant association. Pooled cohort study results indicated no association between postmenopausal risk and GL intake (RR I.03, 95\% Cl 0.94- I.I2). Our findings do not provide strong support of an association between dietary Gl and GL and breast cancer risk. British Journal of Cancer (2008) 99, I I70- | 175. doi:I0.1038/sj.bjc.66046 I 8 www.bjcancer.com

Published online 26 August 2008

(c) 2008 Cancer Research UK
\end{abstract}

Keywords: glycaemic index; glycaemic load; breast cancer; meta-analysis

Glycaemic index (GI) values classify foods according to the 2-h blood glucose response after consuming a portion of the food containing $50 \mathrm{~g}$ of available carbohydrate, compared with the equivalent amount from a standard food, such as glucose or white bread (Jenkins et al, 1981). The glycaemic load (GL) concept was later developed to better reflect the blood glucose response and insulin demand of a food by taking into account the total amount of carbohydrate usually consumed in addition to its GI value (Salmeron et al, 1997).

Habitual consumption of a high GI or GL diet may promote carcinogenesis by inducing hyperglycaemia and hyperinsulinaemia (Brand-Miller, 2003), potentially acting through the insulin-like growth factor (IGF) axis (Biddinger and Ludwig, 2005). A recent meta-analysis illustrated that IGF-1 levels were associated with premenopausal but not postmenopausal breast cancer risk (Renehan et al, 2006). Additionally, high GI diets may promote weight gain (Brand-Miller et al, 2002). High body fatness contributes to an increased risk of postmenopausal, yet a reduced risk of premenopausal, breast cancer (Renehan et al, 2008). There has been a recent surge in research of the effect of GI and GL intake on breast cancer risk; however, results to date have been conflicting (Augustin et al, 2001; Key and Spencer, 2007; McCann et al, 2007). This may not be surprising, given the disparities between the biologically plausible mechanisms suggested above.

In this systematic review, we had the aim of clarifying any association between dietary GI, GL and breast cancer risk, and of

*Correspondence: HG Mulholland; E-mail: hmulholland04@qub.ac.uk Received 15 May 2008; revised 21 July 2008; accepted 27 July 2008; published online 26 August 2008 determining if risk varies according to menopausal status or body fatness.

\section{MATERIALS AND METHODS}

Ovid Medline, including Medline In-Process (US National Library of Medicine, Bethesda, MD, USA), and Embase (Reed Elsevier PLC, Amsterdam, Netherlands) databases were systematically searched for relevant studies published up to May 2008. The search strategy incorporated various medical search heading terms and keywords for GI, GL, nutrition and cancer. Animal studies were excluded but no language restrictions were imposed. The inclusion criteria included both cohort and case-control studies that had assessed dietary GI and/or GL intake in their study population and reported adequate information regarding cancer incidence, including relative risk (RR) estimates and corresponding 95\% confidence intervals (CIs).

Two independent reviewers (HGM, MMC) screened studies for inclusion by examining abstracts and then full text where necessary, with discrepancies resolved by discussion. The reference lists of all included studies were also searched. The reviewers extracted information on study design, population characteristics, exclusion criteria, dietary assessment of GI and GL, adjustments for confounders and results from each study. The NewcastleOttawa quality assessment scale (www.lri.ca) was applied to all studies to consider factors such as selection of participants, comparability of studies, follow-up and ascertainment of exposure and outcome.

Meta-analyses were conducted using studies that compared categories of GI or GL intake to produce risk estimates and presented results separately by menopausal status. Studies 
categorised intake by quartiles (McCann et al, 2007; Sieri et al, 2007; Lajous et al, 2008) or quintiles (Augustin et al, 2001; Cho et al, 2003; Jonas et al, 2003; Frazier et al, 2004; Higginbotham et al, 2004; Holmes et al, 2004; Lajous et al, 2005; Silvera et al, 2005). Two studies could not be included in meta-analyses, as GI/GL intakes were only examined as continuous variables (Nielsen et al, 2005; Giles et al, 2006), and another study was excluded, as it did not present results separately by menopausal status (Levi et al, 2002). Adjusted RR estimates and 95\% CI comparing the highest versus the lowest category of GI and GL intake were combined and weighted using a random-effects model. Sensitivity analysis was performed for cohort and case-control studies separately, premenopausal versus postmenopausal women, by body mass index (BMI) categories where possible, by dietary assessment methods used, by GI/GL values, by follow-up time for cohort studies, by quality scale score, by geographic variations and by systematically removing each individual study. Heterogeneity in each meta-analysis was investigated using the $\chi^{2}$ test and $I^{2}$ statistic. Funnel plots of study relative risks plotted against their corresponding standard errors were assessed for asymmetry to test for publication bias. Statistical analysis was conducted using Intercooled STATA version 9.2 (StataCorp 2005, College Station, TX, USA).

\section{RESULTS}

The electronic database searches identified 464 publications, and 2 independent reviewers screened abstracts, titles then full text to select 51 articles, which were relevant for data extraction on GI, GL and risk of all cancers. Four articles were multiple publications from the same study and one further article did not provide sufficient information on their results, and hence were excluded. Of the remaining studies, 14 specifically referred to breast cancer risk (Augustin et al, 2001; Levi et al, 2002; Cho et al, 2003; Jonas et al, 2003; Frazier et al, 2004; Higginbotham et al, 2004; Holmes et al, 2004; Lajous et al, 2005, 2008; Nielsen et al, 2005; Silvera et al, 2005; Giles et al, 2006; McCann et al, 2007; Sieri et al, 2007), the characteristics of which are summarised in Table 1 . Cohort studies accounted for 10, one of which was a retrospective design, and the remaining 4 publications were case-control studies. Eight studies originated from North and Central America, five from Europe and one from Australia.

Cohort studies scored more highly on the quality scale compared with population-based case-control studies, which in turn ranked higher than hospital-based case-control studies (Table 1). In case-control studies, cases were identified by histological confirmation, whereas cohort studies identified cases through linkage to cancer registries, self-report, medical record review or a combination of these methods. Food Frequency Questionnaires (FFQs) were used in all studies to assess habitual dietary intake, and two cohorts repeated dietary assessment at multiple time points and subsequently were able to calculate cumulative average GI/GL intakes (Cho et al, 2003; Holmes et al, 2004). Most studies sourced GI and GL values from International Tables (Foster-Powell and Miller, 1995; Foster-Powell et al, 2002), with the exception of Sieri et al (2007), who primarily used GI and GL values calculated from their local Italian foods. The majority of studies included age, BMI and energy intake in their adjusted analysis and all that were included in meta-analyses adjusted for women's reproductive and menstrual histories (Table 1). In addition, only two studies controlled for history of diabetes among breast cancer cases (Augustin et al, 2001; Jonas et al, 2003).

There was evidence of marked heterogeneity in analyses of GI/GL intake and breast cancer risk when all studies were combined and therefore analyses were restricted to cohort studies only. As shown in Figure 1, there was some evidence of an association between the highest versus the lowest category of GI intake and premenopausal (RR 1.14, 95\% CI 0.95-1.38) and postmenopausal (RR $1.11,95 \%$ CI $0.99-1.25$ ) risk when six cohort study results were combined; however, these did not reach statistical significance. Although not statistically significant, moderate heterogeneity was still observed, which was not reduced when studies were grouped by differences in their quality scale score, cohort follow-up time, geographic variations or median GI/GL values. When analysis was restricted to cohort studies that had incorporated a more robust measure of dietary intake, that is, $\geqslant 100$-item FFQ, heterogeneity was somewhat reduced and a significant association emerged between GI intake and premenopausal (RR 1.20, 95\% CI $1.01-1.43, I^{2}=37 \%, P=0.17$ ) and postmenopausal risk (RR $1.1095 \%$ CI $1.02-1.19, I^{2}=0 \%$, $P=0.46)$. Significant heterogeneity was observed when the results of case-control studies examining premenopausal $\left(I^{2}=64 \%\right.$, $P=0.05)$ or postmenopausal risk $\left(I^{2}=83 \%, P<0.01\right)$ were combined and so the pooled estimate is not presented. However, only the hospital-based case-control study demonstrated a positive association between GI intake and breast cancer risk. None of the studies that were excluded from our meta-analyses demonstrated an association with GI intake, two of which were conducted in postmenopausal women and one that combined premenopausal and postmenopausal women (Levi et al, 2002; Nielsen et al, 2005; Giles et al, 2006).

There was a lack of symmetry in the funnel plot of GL and premenopausal breast cancer, the results indicating possible publication bias. As shown in Figure 2, most studies did not demonstrate any evidence of an association between the highest versus the lowest category of GL intake and premenopausal risk, with one notable exception (Sieri et al, 2007). There was evidence of heterogeneity when combining cohort studies $\left(I^{2}=69 \%\right.$, $P<0.01$ ), and therefore no combined risk estimate is presented, but removing the study by Sieri et al revealed no association between GL and premenopausal risk (RR 1.02, 95\% CI 0.89-1.16, $\left.I^{2}=9 \%, P=0.35\right)$. Combining data from cohort studies demonstrated no evidence of an association between postmenopausal risk in the highest GL consumers (RR 1.03, 95\% CI 0.94-1.12). Significant heterogeneity was incorporated when combining casecontrol studies, and therefore no combined estimate is presented, although results from these were inconsistent. Two studies examined GL as continuous variables but did not identify any significant association with breast cancer risk (Nielsen et al, 2005; Giles et al, 2006).

Five studies presented GI, GL and breast cancer risk results stratified by BMI categories (Cho et al, 2003; Holmes et al, 2004; Silvera et al, 2005; McCann et al, 2007) and the observed associations did not differ when these were combined separately for normal weight or overweight women (data not shown).

\section{DISCUSSION}

This systematic review and meta-analyses of GI and GL intake and breast cancer risk is the most comprehensive to date and the first to examine the association by menopausal status. Overall, we did not find any strong association between these dietary carbohydrate measures in relation to either premenopausal or postmenopausal risk.

Although no significant association was observed between the highest versus the lowest category of GI intake and breast cancer risk, positive associations became apparent once analysis was restricted to cohort studies utilising a more robust measure of dietary intake, that is, $\geqslant 100$-item FFQs. However, in our systematic review, we performed many stratified analyses to reduce statistical heterogeneity, and therefore any associations shown could have been due to chance. Furthermore, most studies that were not included in our meta-analysis did not observe significant associations with GI (Nielsen et al, 2005; Giles et al, 2006). 
Table I Characteristics of studies included in systematic review of dietary glycaemic index, glycaemic load and risk of breast cancer

Adjusted confounders

\begin{tabular}{|c|c|c|c|c|c|c|c|c|c|c|c|c|c|c|c|c|c|c|c|c|}
\hline $\begin{array}{l}\text { Authors (date), } \\
\text { location }\end{array}$ & Study & $\begin{array}{l}\text { Study design } \\
\text { (mean follow-up) }\end{array}$ & Cases & $\begin{array}{l}\text { Controls/ } \\
\text { cohort } \\
\text { size }\end{array}$ & $\begin{array}{l}\text { Diet } \\
\text { assessment }\end{array}$ & $\begin{array}{l}\text { Quality } \\
\text { scale } \\
\text { score }\end{array}$ & $\begin{array}{l}\text { Median GI } \\
\text { (IQ range) }\end{array}$ & $\begin{array}{l}\text { Median GL } \\
\text { (IQ range) }\end{array}$ & Age & BMI & Energy & Hormon. & Reprod. & Menstr. & Smoking & PA & Education & Alcohol & Family & BBD \\
\hline $\begin{array}{l}\text { Lajous et al } \\
\text { (2008), France }\end{array}$ & E3N Study & 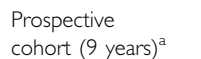 & 1812 & 62739 & $\begin{array}{l}\text { Self-reported } \\
208 \text {-item FFQ }\end{array}$ & 9/9 & $55(44-66)$ & $123(84-165)$ & $r$ & $\nu$ & $\nu$ & $r$ & $r$ & $\nu$ & & $r$ & $\nu$ & $\nu$ & $v$ & $r$ \\
\hline $\begin{array}{l}\text { Sieri et al } \\
\text { (2007), Italy }\end{array}$ & ORDET Study & $\begin{array}{l}\text { Prospective } \\
\text { cohort (1 } 1.5 \text { years) }\end{array}$ & 289 & 8959 & $\begin{array}{l}\text { Self-reported } \\
\text { 107-item FFQ }\end{array}$ & $8 / 9$ & $56(52-59)$ & $1 \mid 3(97-151)$ & $r$ & $r$ & $r$ & $r$ & $r$ & $r$ & $r$ & & $r$ & $r$ & & \\
\hline $\begin{array}{l}\text { McCann et al } \\
\text { (2007), USA }\end{array}$ & WEB Study & $\begin{array}{l}\text { Population-based } \\
\text { case-control }\end{array}$ & 1166 & 2105 & $\begin{array}{l}\text { Interviewed } \\
\text { FFQ }\end{array}$ & 7/9 & $77(70-83)^{b}$ & $147(104-186)^{b}$ & $r$ & $\boldsymbol{r}$ & $r$ & & $r$ & $r$ & & & $r$ & & $r$ & $\boldsymbol{r}$ \\
\hline $\begin{array}{l}\text { Giles et al } \\
\text { (2006), } \\
\text { Australia }\end{array}$ & $\begin{array}{l}\text { Melbourne } \\
\text { Collaborative } \\
\text { Cohort Study }\end{array}$ & $\begin{array}{l}\text { Prospective } \\
\text { cohort } \\
\text { (9.1 years) }\end{array}$ & 324 & 12273 & $\begin{array}{l}\text { Self-reported } \\
|2| \text {-item FFQ }\end{array}$ & 9/9 & $49(46-53)$ & $108(77-150)$ & $r$ & \# & $r$ & $r$ & \# & \# & & \# & \# & \# & \# & \\
\hline $\begin{array}{l}\text { Nielsen et al } \\
\text { (2005), Denmark }\end{array}$ & $\begin{array}{l}\text { Diet, Cancer \& } \\
\text { Health Cohort }\end{array}$ & $\begin{array}{l}\text { Prospective } \\
\text { cohort ( } 6.6 \text { years) }\end{array}$ & 634 & 23870 & $\begin{array}{l}\text { Self-reported } \\
192 \text {-item FFQ }\end{array}$ & 9/9 & - & - & $r$ & $r$ & & $r$ & $r$ & & & & $r$ & $r$ & & \\
\hline $\begin{array}{l}\text { Silvera et al } \\
\text { (2005), Canada }\end{array}$ & $\begin{array}{l}\text { National Breast } \\
\text { Screening Study }\end{array}$ & $\begin{array}{l}\text { Prospective } \\
\text { cohort (16.6 years) }\end{array}$ & 2518 & 49111 & $\begin{array}{l}\text { Self-reported } \\
\text { 86-item FFQ }\end{array}$ & 9/9 & $77(60-96)$ & $104(83-123)$ & $r$ & $r$ & $r$ & $r$ & $r$ & $r$ & & & & $r$ & $r$ & $r$ \\
\hline $\begin{array}{l}\text { Lajous et al } \\
\text { (2005), Mexico }\end{array}$ & & $\begin{array}{l}\text { Population-based } \\
\text { case-control }\end{array}$ & 475 & 1391 & $\begin{array}{l}\text { Interviewed } \\
\text { FFQ }\end{array}$ & $7 / 9$ & $62(-)$ & $152(44-214)$ & $r$ & $r$ & $r$ & & $r$ & $r$ & & & & & $r$ & \\
\hline $\begin{array}{l}\text { Higginbotham } \\
\text { et al (2004), USA }\end{array}$ & $\begin{array}{l}\text { Women's Health } \\
\text { Study }\end{array}$ & $\begin{array}{l}\text { Prospective cohort } \\
\text { (6.8 years) }\end{array}$ & 946 & 38446 & $\begin{array}{l}\text { Self-reported } \\
|3| \text {-item FFQ }\end{array}$ & 9/9 & $53(50-55)$ & $117(92-143)$ & $r$ & $r$ & $r$ & $r$ & $r$ & $r$ & $r$ & $r$ & & $r$ & $r$ & \\
\hline $\begin{array}{l}\text { Holmes et al } \\
\text { (2004), USA }\end{array}$ & $\begin{array}{l}\text { Nurses' Health } \\
\text { Study }\end{array}$ & $\begin{array}{l}\text { Prospective } \\
\text { cohort (18 years) }\end{array}$ & 4092 & 88678 & $\begin{array}{l}\text { Multiple } \\
\text { self-reported } \\
61+\text { item FFQs }\end{array}$ & $8 / 9$ & $75(69-81)$ & $105(81-130)$ & $r$ & $r$ & $r$ & & $r$ & $r$ & & & & $r$ & $r$ & $r$ \\
\hline $\begin{array}{l}\text { Frazier et al } \\
\text { (2004), USA }\end{array}$ & $\begin{array}{l}\text { Nurses' Health } \\
\text { Study II }\end{array}$ & $\begin{array}{l}\text { Retrospective } \\
\text { cohort }\end{array}$ & 361 & 47355 & $\begin{array}{l}\text { Self-reported } \\
\text { |3|-item FFQ }\end{array}$ & $8 / 9$ & 79 (74-84) & $170(|4|-202)$ & $r$ & $r$ & $\boldsymbol{r}$ & $r$ & $r$ & $r$ & & & & $\boldsymbol{r}$ & $r$ & $\boldsymbol{r}$ \\
\hline $\begin{array}{l}\text { Cho et al } \\
\text { (2003), USA }\end{array}$ & $\begin{array}{l}\text { Nurses' Health } \\
\text { Study II }\end{array}$ & $\begin{array}{l}\text { Prospective } \\
\text { cohort (8 years) })^{\text {a }}\end{array}$ & 714 & 90655 & $\begin{array}{l}\text { Self-reported } \\
\text { 133-item FFQ } \\
\text { | } 42 \text {-item FFQ }\end{array}$ & $8 / 9$ & $77(70-82)$ & $120(97-148)$ & $r$ & $r$ & $r$ & $r$ & $r$ & $r$ & $r$ & & & $r$ & $r$ & $r$ \\
\hline $\begin{array}{l}\text { Jonas et al } \\
\text { (2003), USA }\end{array}$ & $\begin{array}{l}\text { CPS II Nutrition } \\
\text { Cohort }\end{array}$ & $\begin{array}{l}\text { Prospective } \\
\text { cohort ( } 5 \text { years) }\end{array}$ & 1442 & 63307 & $\begin{array}{l}\text { Self-reported } \\
68 \text {-item FFQ }\end{array}$ & $8 / 9$ & $74(65-85)$ & $81(58-103)$ & $r$ & $r$ & $\nu$ & $r$ & $\nu$ & $r$ & $\nu$ & $r$ & $\nu$ & $\nu$ & $v$ & $r$ \\
\hline $\begin{array}{l}\text { Levi et al (2002), } \\
\text { Switzerland }\end{array}$ & & $\begin{array}{l}\text { Hospital-based } \\
\text { case-control }\end{array}$ & 331 & 534 & $\begin{array}{l}\text { Interviewed } \\
\text { 79-item FFQ }\end{array}$ & $6 / 9$ & $92(73-1 / 2)$ & - & $r$ & & $r$ & $r$ & $r$ & $r$ & & $r$ & $r$ & $r$ & & \\
\hline $\begin{array}{l}\text { Augustin et al } \\
(200 \mid) \text {, Italy }\end{array}$ & & $\begin{array}{l}\text { Hospital-based } \\
\text { case-control }\end{array}$ & 2569 & 2588 & $\begin{array}{l}\text { Interviewed } \\
\text { 78-item FFQ }\end{array}$ & $6 / 9$ & $74(70-79)$ & $132(98-174)$ & $r$ & & $r$ & $r$ & $r$ & $r$ & & $r$ & $r$ & $\boldsymbol{r}$ & & \\
\hline
\end{tabular}

CPS = Cancer Prevention Study; E3N = French component of European Prospective Investigation into Diet and Cancer Study; ORDET = Hormones and Diet in Etiology of Breast Tumors Study; WEB = Western New York

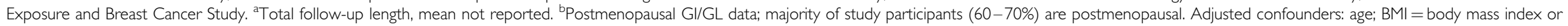

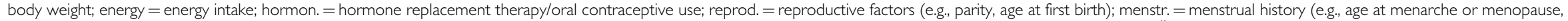
menopausal status); smoking; PA = physical activity; education; alcohol = alcohol intake; family = family history of breast cancer; $\mathrm{BBD}=$ history of benign breast disease. ${ }^{\#}$ confounder tested but not included in final model. 
GI, GL and breast cancer risk

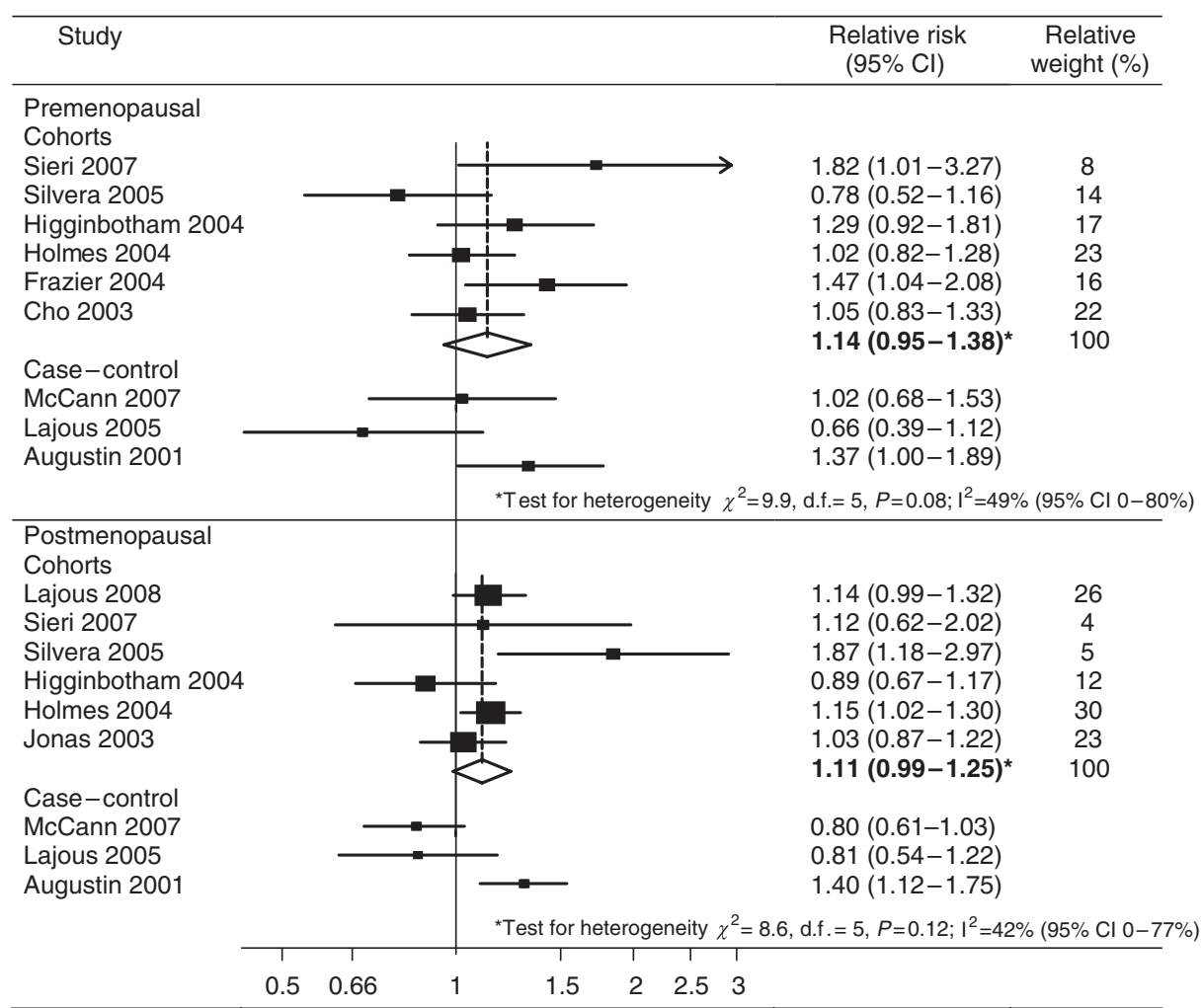

Figure I Forest plot of highest versus lowest category of $\mathrm{Gl}$ intake and breast cancer risk. Bold relative risks denote combined effect estimates.

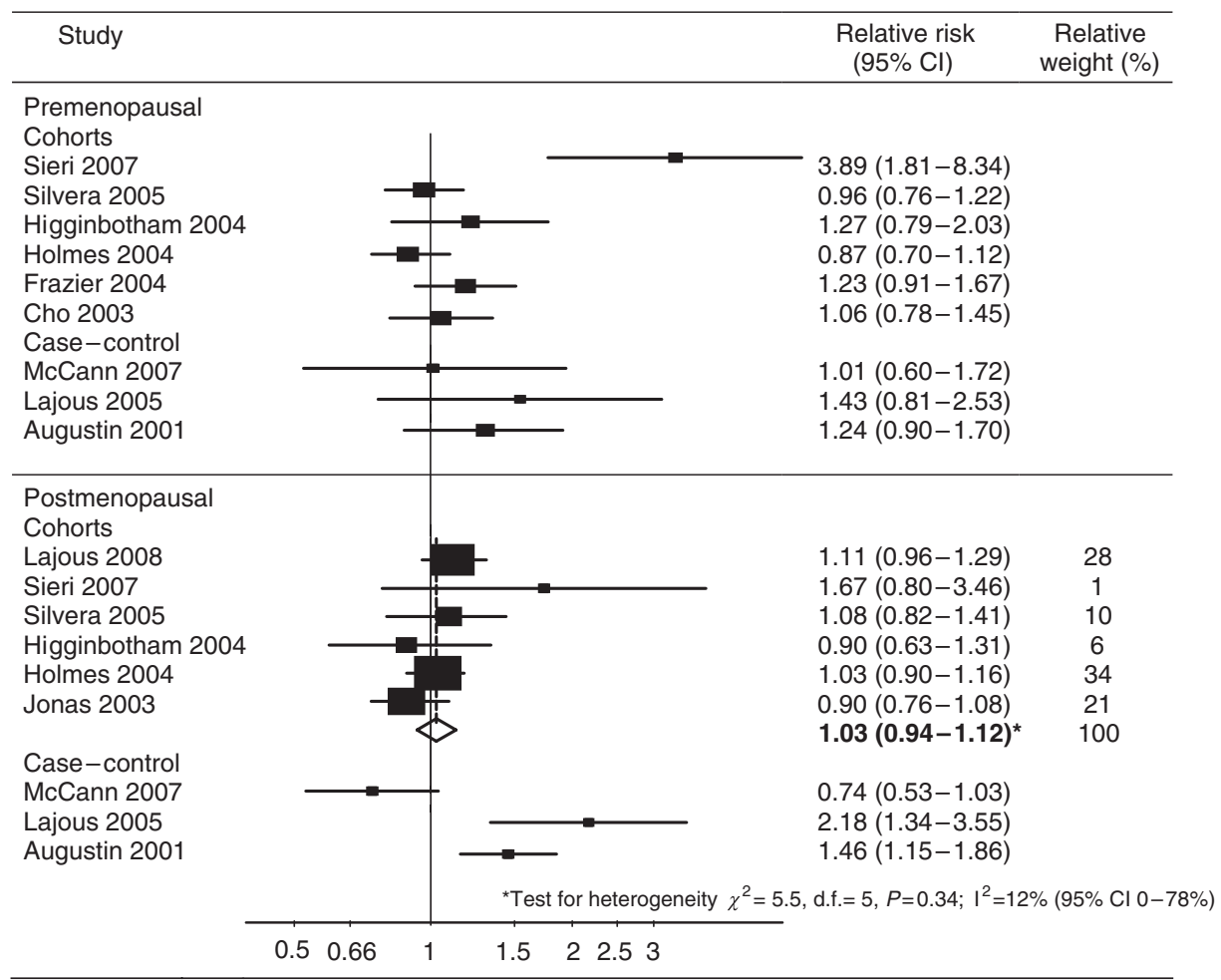

Figure 2 Forest plot of highest versus lowest category of GL intake and breast cancer risk. Bold relative risks denote combined effect estimates.

There was some evidence of publication bias when examining funnel plots of GL and premenopausal breast cancer risk, although the majority of studies reported no significant associations. Our findings also provided little evidence of an association between GL intake and postmenopausal risk. A recent meta-analysis of 20 studies demonstrated a 1.2 -fold increase in risk for women with 
diabetes mellitus (Larsson et al, 2007), suggesting that hyperinsulinaemia may be a contributory factor in breast cancer. However, if risk is related to the overall insulin demand of the diet, stronger associations would be expected for GL rather than GI (Key, 2001) and we observed no association between GL and breast cancer risk. Additionally, C-peptide, a marker of insulin secretion, was not found to be related to risk in two well-designed cohort studies (Verheus et al, 2006; Eliassen et al, 2007), and so there is little evidence to support a direct association between insulin and breast carcinogenesis.

It has been hypothesised that chronic hyperinsulinaemia induced by a high GI diet may suppress fat oxidation and promote carbohydrate oxidation in the body, resulting in an enhanced appetite and body fat gain (Brand-Miller et al, 2002). We did not observe any association between GI/GL intake and breast cancer risk by BMI categories in our limited analysis. However, only five studies reported risk by BMI and none of these were powered to include obese women as a separate subgroup (Cho et al, 2003; Holmes et al, 2004; Silvera et al, 2005; McCann et al, 2007), therefore further research is warranted in this population subgroup.

It is possible that dietary measurement error associated with FFQs may have attenuated any real association between GI, GL and breast cancer risk. The FFQs used were quite variable in length, ranging from 61 items to 192 items in length and only two studies incorporated repeat dietary assessments at different time points to account for potential changes in dietary habits during the followup period (Cho et al, 2003; Holmes et al, 2004). Importantly, individual studies reported in this review collected information about menopausal status only at baseline, which after long follow-

\section{REFERENCES}

Augustin LS, Dal Maso L, La Vecchia C, Parpinel M, Negri E, Vaccarella S, Kendall CW, Jenkins DJ, Franceschi S (2001) Dietary glycemic index and glycemic load, and breast cancer risk: a case-control study. Ann Oncol 12: $1533-1538$

Biddinger SB, Ludwig DS (2005) The insulin-like growth factor axis: a potential link between glycemic index and cancer. Am J Clin Nutr 82: 277-278, doi:82/2/277

Brand-Miller JC (2003) Glycemic load and chronic disease. Nutr Rev 61: S49 - S55

Brand-Miller JC, Holt SH, Pawlak DB, McMillan J (2002) Glycemic index and obesity. Am J Clin Nutr 76: S281 - S285

Cho E, Spiegelman D, Hunter DJ, Chen WY, Colditz GA, Willett WC (2003) Premenopausal dietary carbohydrate, glycemic index, glycemic load, and fiber in relation to risk of breast cancer. Cancer Epidemiol Biomarkers Prev 12: $1153-1158$

Eliassen AH, Tworoger SS, Mantzoros CS, Pollak MN, Hankinson SE (2007) Circulating insulin and c-peptide levels and risk of breast cancer among predominately premenopausal women. Cancer Epidemiol Biomarkers Prev 16: 161 - 164, doi:10.1158/1055-9965

Foster-Powell K, Holt SH, Brand-Miller JC (2002) International table of glycemic index and glycemic load values: 2002. Am J Clin Nutr 76: 5-56

Foster-Powell K, Miller JB (1995) International tables of glycemic index. Am J Clin Nutr 62: S871 - S890

Frazier AL, Li L, Cho E, Willett WC, Colditz GA (2004) Adolescent diet and risk of breast cancer. Cancer Causes Control 15: 73-82, doi:10.1023/ B:CACO.0000016617.57120

Giles GG, Simpson JA, English DR, Hodge AM, Gertig DM, Macinnis RJ, Hopper JL (2006) Dietary carbohydrate, fibre, glycaemic index, glycaemic load and the risk of postmenopausal breast cancer. Int $J$ Cancer 118: 1843 - 1847, doi:10.1002/ijc.21548

Higginbotham S, Zhang ZF, Lee IM, Cook NR, Buring JE, Liu S (2004) Dietary glycemic load and breast cancer risk in the Women's Health Study. Cancer Epidemiol Biomarkers Prev 13: 65-70

Holmes MD, Liu S, Hankinson SE, Colditz GA, Hunter DJ, Willett WC (2004) Dietary carbohydrates, fiber, and breast cancer risk. Am J Epidemiol 159: $732-739$

Jenkins DJ, Wolever TM, Taylor RH, Barker H, Fielden H, Baldwin JM, Bowling AC, Newman HC, Jenkins AL, Goff DV (1981) Glycemic index of up periods, for example, in the Canadian Breast Screening Study and the US Nurses Health Study (Holmes et al, 2004; Silvera et al, 2005), are likely to be inaccurate at the time of analysis. Future studies should ideally collect information on BMI and menopausal status at multiple time points during follow-up periods.

Our meta-analysis has limitations; for example, the study results were inconsistently adjusted for potential confounders (e.g., history of diabetes), which might result in residual confounding. Each study in the meta-analyses had categorised GI and GL intake differently, and utilised a mixture of glucose and white bread reference values. Therefore, we assessed risk in the highest compared with the lowest category of intake, although absolute GI and GL intake within these categories differed between studies, which is not ideal. A relatively small number of studies were included in our analyses, particularly for subgroup analysis, which made it difficult to estimate publication bias and heterogeneity. Nevertheless this meta-analysis achieved reasonable statistical power. In conclusion, our systematic review suggests that high dietary GI and GL intakes do not appear to be of aetiological importance in breast tumour development.

\section{ACKNOWLEDGEMENTS}

We acknowledge Ms Alex McIlroy for her assistance in developing the electronic search strategy used in the systematic review. HG Mulholland is funded by a PhD studentship from the Department for Employment and Learning, UK. foods: a physiological basis for carbohydrate exchange. Am J Clin Nutr 34: $362-366$

Jonas CR, McCullough ML, Teras LR, Walker-Thurmond KA, Thun MJ, Calle EE (2003) Dietary glycemic index, glycemic load, and risk of incident breast cancer in postmenopausal women. Cancer Epidemiol Biomarkers Prev 12: $573-577$

Key TJ (2001) Glycemic index, hyperinsulinemia, and breast cancer risk. Ann Oncol 12: $1507-1509$

Key TJ, Spencer EA (2007) Carbohydrates and cancer: an overview of the epidemiological evidence. Eur J Clin Nutr 61(Suppl 1): S112-S121, doi:10.1038/sj.ejcn.1602941

Lajous M, Boutron-Ruault MC, Fabre A, Clavel-Chapelon F, Romieu I (2008) Carbohydrate intake, glycemic index, glycemic load, and risk of postmenopausal breast cancer in a prospective study of French women. Am J Clin Nutr 87: 1384-1391

Lajous M, Willett W, Lazcano-Ponce E, Sanchez-Zamorano LM, Hernandez-Avila M, Romieu I (2005) Glycemic load, glycemic index, and the risk of breast cancer among Mexican women. Cancer Causes Control 16: 1165-1169, doi:10.1007/s10552-005-0355-x

Larsson SC, Mantzoros CS, Wolk A (2007) Diabetes mellitus and risk of breast cancer: a meta-analysis. Int J Cancer 121: 856-862, doi:10.1002/ ijc. 22717

Levi F, Pasche C, Lucchini F, Bosetti C, La Vecchia C (2002) Glycaemic index, breast and colorectal cancer. Ann Oncol 13: 1688-1689

McCann SE, McCann WE, Hong CC, Marshall JR, Edge SB, Trevisan M, Muti P, Freudenheim JL (2007) Dietary patterns related to glycemic index and load and risk of premenopausal and postmenopausal breast cancer in the Western New York Exposure and Breast Cancer Study. Am J Clin Nutr 86: 465-471

Nielsen TG, Olsen A, Christensen J, Overvad K, Tjonneland A (2005) Dietary carbohydrate intake is not associated with the breast cancer incidence rate ratio in postmenopausal Danish women. J Nutr 135: $124-128$, doi: $135 / 1 / 124$

Renehan AG, Harvie M, Howell A (2006) Insulin-like growth factor (IGF)-I, IGF binding protein-3, and breast cancer risk: eight years on. Endocr Relat Cancer 13: 273-278, doi:10.1677/erc.1.01219

Renehan AG, Tyson M, Egger M, Heller RF, Zwahlen M (2008) Body-mass index and incidence of cancer: a systematic review and meta-analysis of 


\section{GI, GL and breast cancer risk}

HG Mulholland et al

prospective observational studies. Lancet 371: 569-578, doi:10.1016/ S0140-6736(08)60269-X

Salmeron J, Ascherio A, Rimm EB, Colditz GA, Spiegelman D, Jenkins DJ, Stampfer MJ, Wing AL, Willett WC (1997) Dietary fiber, glycemic load, and risk of NIDDM in men. Diabetes Care 20: 545-550

Sieri S, Pala V, Brighenti F, Pellegrini N, Muti P, Micheli A, Evangelista A, Grioni S, Contiero P, Berrino F, Krogh V (2007) Dietary glycemic index, glycemic load, and the risk of breast cancer in an Italian prospective cohort study. Am J Clin Nutr 86: 1160-1166

Silvera SA, Jain M, Howe GR, Miller AB, Rohan TE (2005) Dietary carbohydrates and breast cancer risk: a prospective study of the roles of overall glycemic index and glycemic load. Int J Cancer 114: 653-658, doi:10.1002/ijc.20796

Verheus M, Peeters PH, Rinaldi S, Dossus L, Biessy C, Olsen A, Tjonneland A, Overvad K, Jeppesen M, Clavel-Chapelon F, Tehard B, Nagel G, Linseisen J, Boeing H, Lahmann PH, Arvaniti A, Psaltopoulou T, Trichopoulou A, Palli D, Tumino R, Panico S, Sacerdote C, Sieri S, van Gils CH, Bueno-deMesquita BH, Gonzalez CA, Ardanaz E, Larranaga N, Garcia CM, Navarro C, Quiros JR, Key T, Allen N, Bingham S, Khaw KT, Slimani N, Riboli E, Kaaks R (2006) Serum C-peptide levels and breast cancer risk: results from the European Prospective Investigation into Cancer and Nutrition (EPIC). Int J Cancer 119: 659-667, doi:10.1002/ijc.21861 